\title{
Exploring gendered patterns of interaction within an inter-professional health care network
}

\author{
Dr. Nelson Aguirre M.D Ph.D Health systems Department, School of Population Health, \\ University of Auckland, New Zealand \\ n.aguirre@auckland.ac.nz
}

Dr. Peter Carswell Ph.D. Senior Lecturer. Health systems Department, School of Population Health, University of Auckland, New Zealand.

p.carwell@auckland.ac.nz

Dr. Tim Kenealy PhD, MBChB. Associated Professor Integrated Care, University of Auckland, New Zealand.

t.kenealy@auckland.ac.nz

\begin{abstract}
Background: Numerous studies have shown gender-based similarity affects interactions in organizational contexts. However, studies in the health care arena have shown contradictory findings.
\end{abstract}

Objective: To explore gender homophily in an inter-professional network comprising doctors and nurses across the primary and secondary care interface in diabetes care.

Methods: A Social Network Analysis was conducted with primary and secondary care clinicians responsible for diabetes care in Auckland New Zealand. Three different methods were used to test gender affinity in 40 health professionals (GPs, endocrinologist and specialist nurses). First, a metric analysis of homophily ranking corrected for potential differences in gender proportions was conducted. Homophily ranking is scored between -1 (perfect heterophily) and 1 (perfect 
medRxiv preprint doi: https://doi.org/10.1101/2020.04.07.20057364; this version posted April 10, 2020. The copyright holder for this preprint (which was not certified by peer review) is the author/funder, who has granted medRxiv a license to display the preprint in perpetuity. It is made available under a CC-BY-NC-ND 4.0 International license .

Page 2 of 19

homophily). We also examined the ego-net composition and measured the density of interactions among men and women in the network.

Results: Gender homophily was close to 0 , indicated that network members were likely to interact with males and females without preferences, a result that was confirmed through ego-net composition.

Conclusions: This study in diabetes managed care network found little evidence to support the impact of gender homophily on communication exchange. This contrasts with other studies in the health care context. Other influences need to be explored at this context.

Key Words: Social Network Analysis, ego-net composition, homophily, healthcare.

\section{BACKGROUND}

Collaboration and communication within organizational and inter-professional networks helps diffusion of information and social influence [1-3]. Inter-professional networks have an instrumental value because they affect outcomes performance, allow better access to critical resources and provide social support $[4,5]$. Network interactions are grouped or clustered according to the individual's characteristics such as race, gender, profession and religion among others $[6,7]$. A number of studies have focused on gender as a factor that may influence interactions within networks. Some of the studies have shown that there are differences between men and women in the way they can access the benefits of the social networks, and about motivations to strengthen links. Many health professions are numerically dominated by either men or women [8]. However, in spite of substantial research on how gender may help network 
medRxiv preprint doi: https://doi.org/10.1101/2020.04.07.20057364; this version posted April 10, 2020. The copyright holder for this preprint (which was not certified by peer review) is the author/funder, who has granted medRxiv a license to display the preprint in perpetuity. It is made available under a CC-BY-NC-ND 4.0 International license .

Page 3 of 19

development in health care [9-11], there are still overlapping and contradictory results [10, 12 , 13].

This study focussed on determining how gender may affect the interactions between health professionals at the primary and secondary care interface. This knowledge is useful for planning and designing inter-professional networks working across and within this interface. A social network approach which seeks to identify social network characteristics and patterns of interaction within a network because the social structure of a network effects individual actions and vice versa [14-16]. Social network analysis can identify the distribution of the social interactions within a network and show how they are clustered [14, 17-19].

\section{LITERATURE REVIEW}

\section{Homophily within inter-professional networks}

The way inter-professional networks are organized and perform is based on the interactions among professionals. Some of the characteristics of the interactions are: the content shared (products or services, information), form (duration and closeness of the interactions), intensity (density and frequency of interactions) [20-22], and the tendency of the individuals to interact with those with similar attributes (homophily) $[23,24]$.

Recent research has examined the effects of homophily according to individuals' similarity of attributes such as age [20], ethnicity [21, 22], religion [23, 24], profession [8], knowledge [25] and gender $[9,26,27]$. Homophily within networks may increase perceptions of interpersonal trust by simplifying process of evaluation and facilitating communication [27, 28]. 
medRxiv preprint doi: https://doi.org/10.1101/2020.04.07.20057364; this version posted April 10, 2020. The copyright holder for this preprint (which was not certified by peer review) is the author/funder, who has granted medRxiv a license to display the preprint in perpetuity. It is made available under a CC-BY-NC-ND 4.0 International license .

Page 4 of 19

Homophily could be induced by the network structure such as the work place, voluntary organizations, schools or friendship circles. Alternatively, network homophily may derive from personal or psychological preferences of network participants [28]. Those preferences may explain variations in homophily within a network, and suggest mechanism in which homophily change over the time.

\section{Gender homophily}

Gender similarity is a substantial subject in the social network literature $[10,21,23,29,30]$. It is defined as the association between social characteristics and interactions between males and females. It constitutes a way in which social life is organised, describing patterns of individuals' interactions based on their gender characteristics $[26,27,31]$.

Researchers have studied gender homophily in social networks such as schools, young unmarried men and women and families among others. Their findings illustrate how women and men are orientated to build ties with similar people. For example men maintain their dominance excluding women from their network and tend to have more gender homophily ties [29], and women have more contacts with neighbours and have more family-oriented relationships than men [26]. Men are likely to obtain information from diverse sources as they are inclined to interact with a large number of weak ties [32], while women prefer "small towns" where everyone knows each other, such that they can receive and provide more support from others, establishing closer relationships [26].

However, the context of human interactions within organizations may introduce several differences. Gender homophily has been studied in different contexts such as communication and 
medRxiv preprint doi: https://doi.org/10.1101/2020.04.07.20057364; this version posted April 10, 2020. The copyright holder for this preprint (which was not certified by peer review) is the author/funder, who has granted medRxiv a license to display the preprint in perpetuity. It is made available under a CC-BY-NC-ND 4.0 International license .

Page 5 of 19

technology companies [27], academic scientists [25,33], entrepreneur founding companies [21, $22]$ and healthcare $[6,34]$ among others. There are some contradictory results, as some studies highlight the importance of gendered relationships as a factor in differentiation of network structures and as associated with power [27], while others do not find gender differences or affinities to interact and establish channels of communication [22, 35].

\section{Gender preferences in healthcare networks}

Gender homophily in healthcare is characterized by health professionals' preferences in gender relationships (i.e. a desire to interact with health professionals of the same gender) [23]. Researchers have studied how interpersonal professional relationships (including gender homophily) may affect diffusion of innovations and the adoption of new practices in healthcare [36-40].

Studies have described gender homophily in healthcare teams, highlighting that male doctors usually interact with male colleagues in seeking for help. Women doctors seek supportive and empathic ties and they are more likely to involve women in their inter-professional networks [8, 34]. Female nurses are more likely to build cross-sex relationships than male doctors [8, 41]. However, induced gender homophily (from numerical availability) is a factor to take an account, as some specialties and health care professions are influenced by sex-segregation. As West and Barron (2005) have outlined nurses in UK are predominantly women and medical specialists in neurology, cardio-thoracic medicine and renal medicine are predominantly male while specialists in dermatology, community health and ophthalmology are predominantly female. 
medRxiv preprint doi: https://doi.org/10.1101/2020.04.07.20057364; this version posted April 10, 2020. The copyright holder for this preprint (which was not certified by peer review) is the author/funder, who has granted medRxiv a license to display the preprint in perpetuity. It is made available under a CC-BY-NC-ND 4.0 International license .

Page 6 of 19

Although gender homophily appears to be a critical factor for network and tie development at the individual level, other studies do not find this association within health care teams [42-44], where other socio-demographic factors such as profession or years of experience are more strongly associated with building ties. Identifying factors that facilitate network development in health care could be a strategy for building successful teams, so that if gender is a characteristic that may affect the way in which health professionals share ideas and knowledge, it should be accounted for in attempts to strengthen the relationships between health professionals at the primary and secondary care interface.

\section{METHODS}

The goal of this paper is to explore gender homophily in an inter-professional network comprising the primary and secondary care interface in diabetes managed care. We hypothesise that the distribution of the interactions is influenced by health professionals' gender. Interactions or ties were defined as formal and informal communication, advice, seeking help or benefit, sharing of resources, information flows, or some other form of interprofessional exchange between health professionals at the primary and secondary care interface $[45,46]$.

\section{Design}

A quantitative cross-sectional study conducted in March 2012 was used to collect sociodemographic information and data for social network analysis.

\section{Setting}

Participants were primary care and secondary care doctors and nurses in South Auckland New Zealand. 
medRxiv preprint doi: https://doi.org/10.1101/2020.04.07.20057364; this version posted April 10, 2020. The copyright holder for this preprint (which was not certified by peer review) is the author/funder, who has granted medRxiv a license to display the preprint in perpetuity. It is made available under a CC-BY-NC-ND 4.0 International license .

Page 7 of 19

\section{Participants}

We invited health professionals from primary care and from secondary care who were involved in the care of the same group of diabetic patients. The first group consisted of general practitioners (GPs) and practice nurses (PNs). The second group included endocrinologists and diabetes nurses specialists (DSNs) who work within the secondary care diabetes service. We invited all GPs located in Counties Manukau and were members of the same Primary Health Organisation and the secondary care group were contacted directly at the main referral hospital at the same area.

\section{Procedures}

This study received ethics approval from the New Zealand Ministry of Health's Northern Regional Health and Disability Ethics Committee NTX/11/EXP/150 dated 19/07/2011. Participants completed a social network questionnaire delivered online using LimeSurvey ${ }^{\circledR}$ software. Reponses were collected electronically. Data were checked, cleaned, and then analysed in SPSS for Windows V.19. The information collected included demographic characteristics, the nature of the relationship (role relationship i.e. GP - specialist) between the respondent with each of his or her colleagues - known as "alters" in the network literature - and the frequency, quality and perceived value of the interactions between health professionals.

For the first method of analysis, four variables were used to calculate homophily $(\mathrm{H})$ using the following formula:

$$
H=v[(a / a+b)-(c / c+d)][(a / a+c)-(b / b+c)]
$$


medRxiv preprint doi: https://doi.org/10.1101/2020.04.07.20057364; this version posted April 10, 2020. The copyright holder for this preprint (which was not certified by peer review) is the author/funder, who has granted medRxiv a license to display the preprint in perpetuity. It is made available under a CC-BY-NC-ND 4.0 International license .

Page 8 of 19

where (a) is the number of ties a person sent to the people of the same gender, (b) is number of ties that an individual sent to the people of the opposite gender, (c) is the number of people of the same gender that the actor could have cited but did not, and (d) is the number of people of the opposite gender the actor could have cited but did not. This calculation effectively corrects for induced homophily, i.e. apparent homophily induced simply by imbalances of gender of potential network-tie partners $[29,47,48]$. Calculated $\mathrm{H}$ ranges from -1 to 1 . Positive values indicate the tendency of individuals to select actors of the same gender in the network (homophily). A zero value indicates a balance between selecting male or female and negative values indicates the tendency to elect actors of the opposite gender (heterophily).

In the second analysis, Ego-net homophily was calculated using UCINET software, which produces a series of alternative measures (for any categorical variable) for each person in the network. "Yules $Q$ " is a measure of similarity with ranges from -1 for perfect heterophily to +1 for perfect homophily. A value 0 means no pattern of homophily. "Correlation" calculates the correlation between the presence or absence of a tie between each ego and each alter in the network and a vector indicating ego and alter similarity on the selected attribute (gender); interpretation is the same as for Yules Q.

\section{RESULTS}

From 50 invitations submitted, 49 valid questionnaires were obtained corresponding to the same number of participants. Every participant reported having contact with patients with diabetes as part of their work. Participants were from primary care $(31,63 \%)$ and secondary care $(18,37 \%)$. General practitioners and practice nurses were located in 17 different general practices, while 
medRxiv preprint doi: https://doi.org/10.1101/2020.04.07.20057364; this version posted April 10, 2020. The copyright holder for this preprint (which was not certified by peer review) is the author/funder, who has granted medRxiv a license to display the preprint in perpetuity. It is made available under a CC-BY-NC-ND 4.0 International license .

Page 9 of 19

secondary care was treated as a single centre (located in a hospital). General practitioners and specialist nurses were the two groups most represented in this study. Overall, 32 participants were female and 17 male, the numbers in primary care were similar but the majority of the secondary care participants were female. Table 1 reports the distribution of health professionals who participated in the study by profession.

\section{Insert TABLE 1 about here}

\section{Participant distribution by profession and sector}

\section{Results of the Corrected Metric Homophily}

Table 2 shows that it was possible to calculate gender-homophily in 40 (82\%) actors (9 actors did not have interactions within the network). There were 6 actors with rank 0 that mean they do not have any gender preference, 2 actors with a negative rank that represent actors who prefer to interact with people of the opposite gender and 32 actors with a positive rank who like to interact with other actors of the same gender.

\section{Insert TABLE 2 about here Network Metric Homophily}

The homophily distribution for the entire network is presented in figure 1 . Most values of the homophily near 0 , suggesting there is no pattern of homophily by gender in this network. 
medRxiv preprint doi: https://doi.org/10.1101/2020.04.07.20057364; this version posted April 10, 2020. The copyright holder for this preprint

(which was not certified by peer review) is the author/funder, who has granted medRxiv a license to display the preprint in perpetuity.

It is made available under a CC-BY-NC-ND 4.0 International license .

Page 10 of 19

Table 3 shows the homophily ranking using UCINET. The correlation indicator shows values close to 0 , suggesting that there are not patterns of homophily by gender in this network.

\section{Density of interaction by gender}

Density of interactions was measured by women and men in this network. As a shown figure 2, there are denser interactions between women than between men.

\section{DISCUSSION}

Using two different methods we found there was no gender homophily in the patterns of interaction between health professionals at the primary and secondary care interface in the diabetes service in Auckland New Zealand. This study confirms strong relationships and tie formation with other colleagues performing collaborative behaviours in similar specialties and interacting organizations, suggesting that gender homophily is not one of the main factors affecting network development in this service. A second aspect to highlight is that women established more interactions with other women particularly within secondary care, in contrast with men. There is an important implication of this pattern, in terms of the speed for spread knowledge and the effectiveness to reach actors in the periphery of the network.

Limitations of this study include the cross-sectional design which does not allow identification of causal relationships. The sample was relatively small and was derived from volunteers within a 
medRxiv preprint doi: https://doi.org/10.1101/2020.04.07.20057364; this version posted April 10, 2020. The copyright holder for this preprint

(which was not certified by peer review) is the author/funder, who has granted medRxiv a license to display the preprint in perpetuity.

It is made available under a CC-BY-NC-ND 4.0 International license .

Page 11 of 19

single primary health organisation and referral hospital, and may not represent all health professionals among the diabetes care programme.

\section{Conclusion}

This study in diabetes managed care network found little evidence to support the impact of gender homophily on communication exchange. This contrasts with other studies in the health care context. Existing literature provides a good understanding of how gender affect network development, but networks are dynamic and increase and decay over the time. This is the reason why research on social networks requires studying interactions within individuals over the time. It will be necessary to identify possible associations between gender and other set of characteristics such as profession and education background, in order to identify potential overlaps and interactions between them that may explain patterns of homophily in healthcare context.

\section{Competing interests}

The authors declare that they have no competing interests.

\section{Authors' contributions}

NA Collected and analysed the data. MM, TK and PC interpreted the data. All authors conceived and designed the study, and drafted the manuscript.

\section{Funding}

None

\section{Acknowledge}


medRxiv preprint doi: https://doi.org/10.1101/2020.04.07.20057364; this version posted April 10, 2020. The copyright holder for this preprint (which was not certified by peer review) is the author/funder, who has granted medRxiv a license to display the preprint in perpetuity. It is made available under a CC-BY-NC-ND 4.0 International license.

Page 12 of 19

The authors would like to thank PROCARE PHO and Counties Manukau DHB for their help with selecting the sample. 
medRxiv preprint doi: https://doi.org/10.1101/2020.04.07.20057364; this version posted April 10, 2020. The copyright holder for this preprint

(which was not certified by peer review) is the author/funder, who has granted medRxiv a license to display the preprint in perpetuity.

It is made available under a CC-BY-NC-ND 4.0 International license .

Page 13 of 19

\section{REFERENCES}

1. Hojat M, Nasca TJ, Cohen MJM, Fields SK, Rattner SL, Griffiths M, Ibarra D, de Gonzalez AA-G, Torres-Ruiz A, Ibarra $G$ et al: Attitudes toward physician-nurse collaboration: a cross-cultural study of male and female physicians and nurses in the united states and mexico. Nursing Research 2001, 50(2):123-128.

2. D'Amour D, Ferrada-Videla M, Rofriguez LSM, Beaulieu M-D: The conceptual basis for interprofessional collaboration: core concepts and theoretical frameworks. Journal of Interprofessional Care 2005, 19 Suppl 1:116 - 131.

3. Powell WW, Koput KW, Smith-Doerr L: Interorganizational Collaboration and the Locus of Innovation: Networks of Learning in Biotechnology. Administrative Science Quarterly 1996, 41(1):116-145.

4. Burt R, Kilduff M, Tasselli S: Social network analysis: Foundations and frontiers on advantage. Annual review of psychology 2013, 64:527-547.

5. Stuart T: Interorganizational alliances and the performance of firms: A study of growth and innovation rates in a high-technology industry. Strategic management journal 2000, 21(8):791811.

6. West E, Barron DN, Dowsett J, Newton JN: Hierarchies and cliques in the social networks of health care professionals: implications for the design of dissemination strategies. Social Science \& Medicine 1999, 48(5):633-646.

7. Reagans R, Zuckerman E, McEvily B: How to Make the Team: Social Networks vs. Demography as Criteria for Designing Effective Teams. Administrative Science Quarterly 2004, 49(1):101-133.

8. West E, Barron DN: Social and Geographical Boundaries Around Senior Nurse and Physician Leaders:An Application of Social Network Analysis. CJNR 2005, 37(3):132-148.

9. Brass D, Galaskiewicz J, Greve HR, Tsai W: Taking stock of networks and organizations: a multilevel perspective. Academy of Management Journal 2004, 47(6):795-817.

10. Ibarra H: Paving an Alternative Route: Gender Differences in Managerial Networks. Social Psychology Quarterly 1997, 60(1):91-102.

11. Mehra A, Dixon A, Brass D, Robertson B: The Social Network Ties of Group Leaders: Implications for Group Performance and Leader Reputation. Organization Science 2006, 17(1):64-79.

12. Cabrera SF, Thomas-Hunt MC: "Street Cred" and the Executive Woman: The Effects of Gender Differences in Social Networks on Career Advancement. Advances in group processes 2007, 24:123-147.

13. Zappa P: The network structure of knowledge sharing among physicians. Quality \& Quantity 2011, 45(5):1109-1126.

14. Wellman B, Frank O, Espinoza V, Lundquist S, Wilson C: Integrating individual, relational and structural analysis. social Networks 1991, 13:223-249.

15. Borgatti S: On network Theory. Organization Science 2011, 22(5):1168-1181.

16. Marsden PV: Social structure and network analysis. London: SAGE; 1982.

17. Heiligers PJ, Jong JDd, Groenewegen PP, Hingstman L, Völker B, Spreeuwenberg P: Is networking different with doctors working part-time? Differences in social networks of part-time and fulltime doctors. BMC Health Services Research 2008, 8(204).

18. Umiker W: Networking: A vital activity for health care professionals. Health care Supervisor 1989, 7(3):65-69.

19. Tichy N, Tushman M, Fonbrum C: Social Network Analysis For Organizations. The Academy of Management Review 1979, 4(4):507-519.

20. Louch H: Personal network integration: transitivity and homophily in strong-tie relations. Social Networks 2000, 22(1):45-64. 
medRxiv preprint doi: https://doi.org/10.1101/2020.04.07.20057364; this version posted April 10, 2020. The copyright holder for this preprint

(which was not certified by peer review) is the author/funder, who has granted medRxiv a license to display the preprint in perpetuity.

It is made available under a CC-BY-NC-ND 4.0 International license .

Page 14 of 19

21. Ruef M, Aldrich HE, Carter NM: The structure of the founding teams: homophily, strong ties, and isolation among U.S. entrepreneurs. American Sociological Review 2003, 68.

22. Kim $\mathrm{P}$, Aldrich $\mathrm{H}$ : Teams that work together, stay together: resiliency of entrepreneurial teams. In: Babson College, Babson Kauffman Entrepreneurship Research Conference (BKERC): 2002; 2002.

23. Levinson R, McCollum K, Kutner N: Gender homophily in preferences for physicians. Sex Roles 1984, 10(5-6):315-325.

24. McPherson JM, Smith-Lovin L: Homophily in Voluntary Organizations: Status Distance and the Composition of Face-to-Face Groups. American Sociological Review 1987, 52(3):370-379.

25. Jha Y, Welch EW: Relational mechanisms governing multifaceted collaborative behavior of academic scientists in six fields of science and engineering. Research Policy 2010, 39(9):11741184.

26. Ridgeway CL, Smith-Lovin L: The Gender System and Interaction. Annual Review of Sociology 1999, 25:191-216.

27. Hanson S, Blake M: Gender and Entrepreneurial Networks. Regional Studies 2009, 43(1):135149.

28. Gueorgi Kossinets, Duncan J. Watts: Origins of Homophily in an Evolving Social Network. American Journal of Sociology 2009, 115(2):405-450.

29. Ibarra H: Homophily and differential returns: sex differences in network structure and access in an advertising firm. Administrative Science Quarterly 1992, 37(3):422-447.

30. McDonald S, Lin N, Ao D: Networks of Opportunity: Gender, Race, and Job Leads. Social Problems 2009, 56(3):385-402.

31. Durbin S: Creating Knowledge through Networks: a Gender Perspective. Gender, Work \& Organization 2011, 18(1):90-112.

32. Granovetter M: The Strength of Weak Ties. The American Journal of Sociology 1973, 78(6):13601380.

33. Rothstein M, Davey LM: Gender differences in network relationships in academia. Women in Management Review 1995, 10(6):20-25.

34. Wallace JE: Gender and Supportive Co-Worker Relations in the Medical Profession. Gender, Work \& Organization 2013:n/a-n/a.

35. Levin DZ, Cross R, Abrams LC: Why should I trust you? Predictors of interpersonal trust in a knowledge transfer context. In: Academy of Management Meeting, Denver, CO: 2002; 2002.

36. Valente T: Social networks thresholds in the disffusion of innovation. Social Networks 1996, 18:69-89.

37. Faulkner A, Mills N, Bainton D, Baxter K, Kinnersley P, Peters TJ, Sharp D: A systematic review of the effect of primarycare-based service innovations on quality and patterns of referral to specialist secondary care. British Journal of General Practice 2003, 53:878-884.

38. Berendsen AJ, Benneker WH, Jong BM-d, Klazinga NS, Schuling J: Motives and preferences of general practitioners for new collaboration models with medical specialists: a qualitative study. BMC Health Services Research 2007, 7(4).

39. Fattorea G, Frosini F, Salvatorec D, Tozzid V: Social network analysis in primary care: The impact of interactions on prescribing behaviour. Health Policy 2009, 92:8.

40. Keating NL, Ayanian JZ, Cleary PD, Marsden PV: Factors affecting influential discussions among physicians: a social network analysis of a primary care practice. Journal of general internal medicine 2007, 22(6):794.

41. Braithwaite J: Between-group behaviour in health care: gaps, edges, boundaries, disconnections, weak ties, spaces and holes. A systematic review. BMC Health Services Research 2010, 10:330-330. 
medRxiv preprint doi: https://doi.org/10.1101/2020.04.07.20057364; this version posted April 10, 2020. The copyright holder for this preprint

(which was not certified by peer review) is the author/funder, who has granted medRxiv a license to display the preprint in perpetuity.

It is made available under a CC-BY-NC-ND 4.0 International license .

Page 15 of 19

42. MacPhee M, Scott J: The role of social support networks for rural hospital nurses. Journal of Nurse Administration 2002, 32(5):264-262.

43. Fattore G, Salvatore D: Network organizations of general practitioners: antecedents of formation and consequences of participation. BMC Health Services Research 2010, 10(118).

44. Konrad AM, Cannings K, Goldberg CB: Asymmetrical demography effects on psychological climate for gender diversity: Differential effects of leader gender and work unit gender composition among Swedish doctors. Human Relations 2010, 63(11):1661-1685.

45. Berendsen AJ, Jong GMd, Jong BM-d, Dekker JH, Schuling J: Transition of care: experiences and preferences of patients across the primary/secondary interface - a qualitative study. $B M C$ Health Services Research 2009, 9(62):8.

46. Foy R, Hempel S, Rubenstein L, Suttorp a, Seelig i, Shanman R, Shekelle PG: Meta-analysis: effect of interactive communication between collaborating primary care physicians and specialists. Annals of Internal Medicine 2010, 152:247-258.

47. Gower JC, Legendre P: Metric and euclidean properties of dissimilarity coefficients. Journal of Classification 1986, 3:5-48.

48. Krackhardt D: Assessing the political landscape structure, cognition, and power in organziations. Administrative Science Quarterly 1990, 35(2):342-369. 
medRxiv preprint doi: https://doi.org/10.1101/2020.04.07.20057364; this version posted April 10, 2020. The copyright holder for this preprint (which was not certified by peer review) is the author/funder, who has granted medRxiv a license to display the preprint in perpetuity.

It is made available under a CC-BY-NC-ND 4.0 International license .

Page 16 of 19

\section{TABLES}

Table 1: Participant distribution by sector, gender and profession.

\begin{tabular}{|c|c|c|c|c|c|c|}
\hline Sector & Male & Female & Profession & $\begin{array}{l}\text { Sample } \\
\text { Number }\end{array}$ & $\begin{array}{c}\text { Total } \\
\text { sample by } \\
\text { sector }\end{array}$ & Universe \\
\hline \multirow{2}{*}{$\begin{array}{c}\text { Primary } \\
\text { care }\end{array}$} & \multirow{2}{*}{14} & \multirow{2}{*}{17} & $\begin{array}{l}\text { General } \\
\text { Practitioner }\end{array}$ & 25 & \multirow{2}{*}{31} & 140 \\
\hline & & & $\begin{array}{l}\text { Practices } \\
\text { Nurse }\end{array}$ & 6 & & $\begin{array}{c}\text { No } \\
\text { reference }\end{array}$ \\
\hline \multirow{2}{*}{$\begin{array}{l}\text { Secondary } \\
\text { care }\end{array}$} & \multirow{2}{*}{3} & \multirow{2}{*}{15} & $\begin{array}{l}\text { Specialist } \\
\text { Doctor }\end{array}$ & 4 & \multirow{2}{*}{18} & 7 \\
\hline & & & $\begin{array}{l}\text { Specialist } \\
\text { Nurse }\end{array}$ & 14 & & 18 \\
\hline
\end{tabular}

Table 2. Network Metric Homophily

\begin{tabular}{|c|c|c|c|c|c|c|}
\hline Participant & Gender & $\begin{array}{c}\text { Ties } \\
\text { same sex }\end{array}$ & Ties opposite sex & $\begin{array}{l}\text { Same sex could cited but did } \\
\text { not }\end{array}$ & $\begin{array}{l}\text { Different sex could cited } \\
\text { but did not }\end{array}$ & $\begin{array}{c}\text { Rank } \\
\text { homophily }\end{array}$ \\
\hline SCN010 & 0 & 16 & 11 & 13 & 7 & -0.07 \\
\hline GD00332 & 1 & 2 & 3 & 16 & 26 & -0.03 \\
\hline GD00114 & 1 & 1 & 1 & 17 & 28 & 0.00 \\
\hline GD00312 & 0 & 1 & 1 & 28 & 17 & 0.00 \\
\hline GD00535 & 1 & 1 & 1 & 17 & 28 & 0.00 \\
\hline GD00930 & 0 & 1 & 1 & 28 & 17 & 0.00 \\
\hline GN00212 & 0 & 1 & 1 & 28 & 17 & 0.00 \\
\hline GN00628 & 0 & 2 & 2 & 27 & 16 & 0.00 \\
\hline GD00926 & 0 & 2 & 1 & 27 & 17 & 0.04 \\
\hline GD00832 & 1 & 1 & 2 & 17 & 27 & 0.05 \\
\hline SCSO03 & 1 & 11 & 19 & 7 & 10 & 0.07 \\
\hline SCN001 & 0 & 16 & 9 & 13 & 9 & 0.08 \\
\hline SCS009 & 1 & 10 & 18 & 8 & 11 & 0.09 \\
\hline GN00632 & 0 & 1 & 2 & 28 & 16 & 0.10 \\
\hline GN00832 & 0 & 1 & 2 & 28 & 16 & 0.10 \\
\hline SCN013 & 0 & 1 & 2 & 28 & 16 & 0.10 \\
\hline GD00330 & 0 & 1 & 0 & 28 & 18 & 0.12 \\
\hline GN00326 & 0 & 1 & 0 & 28 & 18 & 0.12 \\
\hline GD00324 & 1 & 0 & 1 & 18 & 28 & 0.14 \\
\hline GD00724 & 0 & 0 & 1 & 29 & 17 & 0.14 \\
\hline GD00628 & 1 & 2 & 6 & 16 & 23 & 0.16 \\
\hline
\end{tabular}


medRxiv preprint doi: https://doi.org/10.1101/2020.04.07.20057364; this version posted April 10, 2020. The copyright holder for this preprint (which was not certified by peer review) is the author/funder, who has granted medRxiv a license to display the preprint in perpetuity.

It is made available under a CC-BY-NC-ND 4.0 International license.

Page 17 of 19

\begin{tabular}{lllllll} 
GD00723 & 1 & 1 & 0 & 17 & 29 & 0.19 \\
SCN004 & 0 & 13 & 5 & 16 & 13 & 0.19 \\
GD00512 & 1 & 0 & 2 & 18 & 27 & 0.20 \\
GN00514 & 0 & 0 & 2 & 29 & 16 & 0.20 \\
SCN007 & 0 & 0 & 2 & 29 & 16 & 0.20 \\
GD00629 & 0 & 3 & 0 & 26 & 18 & 0.21 \\
SCN009 & 0 & 3 & 0 & 26 & 18 & 0.21 \\
GD00335 & 1 & 1 & 5 & 17 & 24 & 0.21 \\
GD00514 & 1 & 1 & 5 & 17 & 24 & 0.21 \\
SCC005 & 0 & 14 & 5 & 15 & 13 & 0.22 \\
SCN011 & 0 & 18 & 7 & 11 & 11 & 0.23 \\
SCN012 & 0 & 13 & 4 & 16 & 14 & 0.24 \\
GD00310 & 1 & 0 & 3 & 18 & 26 & 0.24 \\
SCN014 & 0 & 12 & 3 & 17 & 15 & 0.27 \\
SCN002 & 0 & 13 & 3 & 16 & 15 & 0.29 \\
SCN003 & 0 & 13 & 3 & 16 & 15 & 0.29 \\
SCN008 & 0 & 13 & 3 & 16 & 15 & 0.29 \\
SCS011 & 0 & 13 & 3 & 16 & 16 & 0.29 \\
SCS010 & 1 & 2 & 13 & 16 & 16 & 0.35 \\
\hline
\end{tabular}

Table 3: Gender homophily using UCINET

\begin{tabular}{lrr}
\multicolumn{1}{c}{ GENDER HOMOPHILY } \\
Actor & YulesQ & Corr/PBSC \\
\hline \hline GD00324 & -1 & \\
GD00512 & -1 & \\
GD00724 & -1 & \\
GN00514 & -1 & \\
SCN007 & -1 & \\
SCS003 & -0.721 & -0.339 \\
GD00926 & -0.568 & -0.156 \\
GN00632 & -0.568 & -0.156 \\
GN00832 & -0.568 & -0.156 \\
SCN013 & -0.568 & -0.156 \\
GN00628 & -0.273 & -0.078 \\
GD00312 & -0.261 & -0.054 \\
GD00930 & -0.261 & -0.054
\end{tabular}


medRxiv preprint doi: https://doi.org/10.1101/2020.04.07.20057364; this version posted April 10, 2020. The copyright holder for this preprint (which was not certified by peer review) is the author/funder, who has granted medRxiv a license to display the preprint in perpetuity. It is made available under a CC-BY-NC-ND 4.0 International license.

Page 18 of 19

\begin{tabular}{|c|c|c|}
\hline GN00212 & -0.261 & -0.054 \\
\hline SCNO10 & -0.158 & -0.076 \\
\hline GD00335 & -0.053 & -0.016 \\
\hline GD00514 & -0.053 & -0.016 \\
\hline GD00310 & -0.049 & -0.011 \\
\hline GD00832 & -0.049 & -0.011 \\
\hline SCS010 & 0.016 & 0.007 \\
\hline GD00628 & 0.054 & 0.019 \\
\hline SCNOO1 & 0.067 & 0.032 \\
\hline SCS009 & 0.073 & 0.034 \\
\hline GD00332 & 0.109 & 0.033 \\
\hline GD00114 & 0.304 & 0.064 \\
\hline GD00535 & 0.304 & 0.064 \\
\hline SCNOO4 & 0.331 & 0.156 \\
\hline ScC005 & 0.389 & 0.187 \\
\hline SCNO11 & 0.404 & 0.205 \\
\hline SCNO12 & 0.456 & 0.214 \\
\hline SCNO14 & 0.538 & 0.244 \\
\hline SCS011 & 0.538 & 0.244 \\
\hline SCNOO2 & 0.585 & 0.274 \\
\hline SCNOO3 & 0.585 & 0.274 \\
\hline SCNOO8 & 0.585 & 0.274 \\
\hline GD00330 & 1 & \\
\hline GD00629 & 1 & \\
\hline GD00723 & 1 & \\
\hline GN00326 & 1 & \\
\hline SCNOO9 & 1 & \\
\hline GD00111 & & \\
\hline GD00120 & & \\
\hline GD00122 & & \\
\hline GD00427 & & \\
\hline GD00429 & & \\
\hline GD00630 & & \\
\hline GD00640 & & \\
\hline GD00731 & & \\
\hline SCNO05 & & \\
\hline
\end{tabular}


medRxiv preprint doi: https://doi.org/10.1101/2020.04.07.20057364; this version posted April 10, 2020. The copyright holder for this preprint (which was not certified by peer review) is the author/funder, who has granted medRxiv a license to display the preprint in perpetuity.

\section{It is made available under a CC-BY-NC-ND 4.0 International license .}

Page 19 of 19

\section{FIGURES}

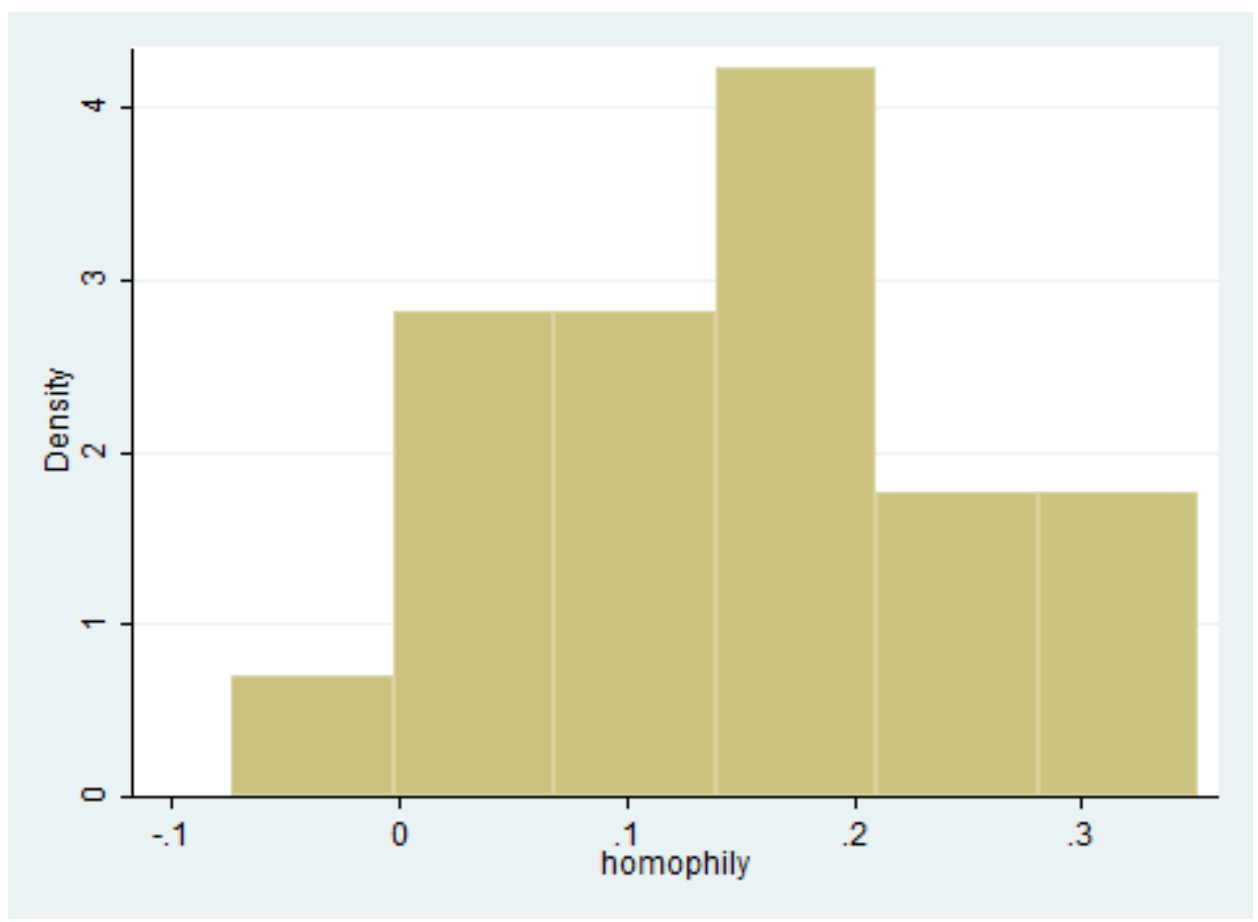

Figure 1. Homophily distribution histogram.
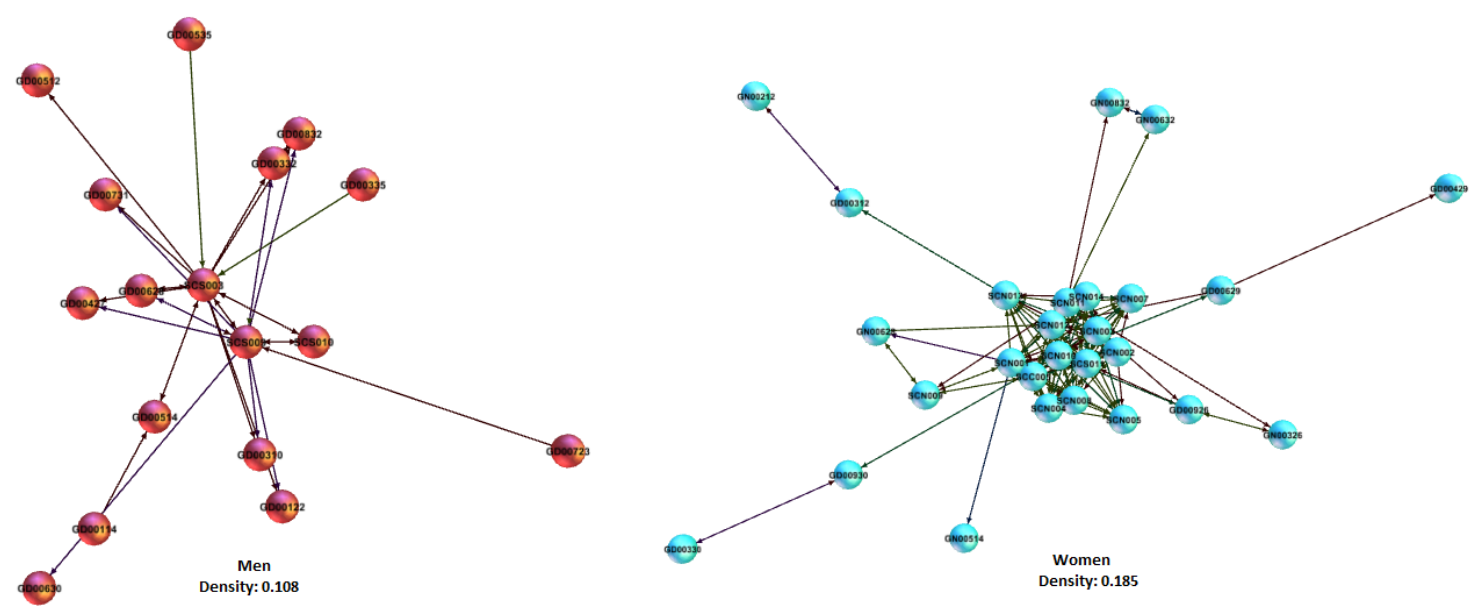

Figure 2. Map of the interactions by gender. Whole network density: 0.156 